\title{
Analysis of Apoptosis and Necroptosis by Fluorescence-Activated Cell Sorting
}

\author{
Fredrik Wallberg, Tencho Tenev, and Pascal Meier ${ }^{1}$ \\ The Breakthrough Toby Robins Breast Cancer Research Centre, Institute of Cancer Research, Chester Beatty \\ Laboratories, London SW3 6JB, United Kindom
}

Fluorescence-activated cell sorting (FACS) is a laser-based, biophysical technology that allows simultaneous multiparametric analysis. For the analysis of dying cells, fluorescently labeled Annexin V (Annexin $\mathrm{V}^{\mathrm{FITC}}$ ) and propidium iodide (PI) are the most commonly used reagents. Instead of PI, 4',6-diamidino-2-phenylindole (DAPI) can also be used. DAPI is a fluorescent stain that binds strongly to A-T-rich regions in DNA. DAPI and PI only inefficiently pass through an intact cell membrane and, therefore, preferentially stain dead cells. DAPI can be combined with Annexin $\mathrm{V}^{\mathrm{FITC}}$ and the potentiometric fluorescent dye, tetramethylrhodamine methyl ester (TMRM), which measures mitochondrial permeability transition and mitochondrial membrane depolarization. TMRM is a cell-permeable fluorescent dye that is sequestered to active mitochondria, and hence labels live cells. On apoptosis or necroptosis the TMRM signal is lost. The advantage of using Annexin $\mathrm{V}^{\mathrm{FITC}} / \mathrm{DAPI} / \mathrm{TMRM}$ is that the entire cell population is labeled, and it is easy to distinguish living (TMRM + /Annexin V VITC-/DAPI-) from dying or dead cells (apoptosis: TMRM-/Annexin $\mathrm{V}^{\mathrm{FITC}}+$ /DAPI-; necrosis: TMRM-/Annexin $\mathrm{V}^{\mathrm{FITC}}+$ /DAPI+). This is important because cell debris (fluorescent negative particles) must be avoided to establish the correct parameters for the FACS analysis, otherwise incorrect statistical values will be obtained. To obtain information on the cell concentration or absolute cell counts in a sample, it is recommended to add an internal microsphere counting standard to the flow cytrometric sample. This protocol describes the FACS analysis of cell death in HT1080 and L929 cells, but it can be readily adapted to other cell types of interest.

It is essential that you consult the appropriate Material Safety Data Sheets and your institution's Environmental Health and Safety Office for proper handling of equipment and hazardous materials used in this protocol.

RECIPES: Please see the end of this protocol for recipes indicated by $<R>$. Additional recipes can be found online at http://cshprotocols.cshlp.org/site/recipes.

Reagents

4',6-Diamidino-2-phenylindole (DAPI)

Annexin $\mathrm{V}^{\mathrm{FITC}}$

$\mathrm{CaCl}_{2}(1 \mathrm{M})$

CountBright Absolute Counting Beads (Life Technologies)

Doxycycline

\footnotetext{
${ }^{1}$ Correspondence: pmeier@icr.ac.uk

(C) 2016 Cold Spring Harbor Laboratory Press

Cite this protocol as Cold Spring Harb Protoc; doi:10.1101/pdb.prot087387
} 
F. Wallberg et al.

Dulbecco's modified Eagle's medium (DMEM) with phenol red (Life Technologies, 41966-029)

Fetal bovine serum (FBS)

HT1080 $0^{\text {indRIPK3 }}$ cells

Parental HT1080 cells (ATCC) were transduced with lentiviral particles carrying RIPK3 CDNA expressed under the control of a doxycycline regulatable promoter. For RIPK3 induction, cells should be cultured in media containing doxycycline $(D O X)(100 \mathrm{ng} / \mathrm{mL})$ for at least $1 \mathrm{wk}$ prior to the experiment.

IAP-antagonist (SMAC mimetic, SM; 1 mM in DMSO)

L929 cells

Necrostatin-1 (Sigma-Aldrich; $40 \mathrm{~mm}$ in DMSO)

Recombinant human TNF (Alexis; $100 \mu \mathrm{g} / \mathrm{mL}$ in DMEM)

Tetramethylrhodamine methyl ester (TMRM) (Life technologies)

Trypsin

zVAD-fmk (20 mм in DMSO)

\section{Equipment}

Cell culture plates (six-well)

BD LSR II FACS system (BD Bioscience) or equivalent

The system needs to be equipped with three lasers: 404, 488, and $561 \mathrm{~nm}$. FITC is excited by the $488 \mathrm{~nm}$ laser and emission light is measured with filters 505 LP 525/50 BP. DAPI is excited by the $404 \mathrm{~nm}$ laser and emission light is collected with filters 450/50 BP (Kapuscinski 1995). TMRM is excited by a $561 \mathrm{~nm}$ laser and emission light is collected with filters 595/40 BP. The CountBright absolute counting beads can be excited by any laser and detected by any filter.

Incubator $\left(37^{\circ} \mathrm{C}, 10 \% \mathrm{CO}_{2}\right.$, humidified $)$

Polystyrene round-bottom FACS tubes $(5 \mathrm{~mL})$

Tissue culture equipment, including a laminar flow hood

Perform Steps 1-3 under a laminar flow hood using aseptic techniques.

1. Seed $3 \times 10^{5}$ cells/well (HT1080 $0^{\text {indRIPK3 }}$ or L929) in $2 \mathrm{~mL}$ of DMEM supplemented with $10 \%$ FBS into six-well plates. Culture cells at $37^{\circ} \mathrm{C}$ under a $10 \% \mathrm{CO}_{2}$ atmosphere.

2. Once the cells have reached $50 \%-60 \%$ confluency, treat them as follows. Ensure sufficient wells are left untreated for use as controls, as described in Step 6.

i. Treat wells of HT1080 indRIPK3 cells for $12 \mathrm{~h}$ with the following combinations of reagents. Use three wells per condition.

- $20 \mu \mathrm{m}$ zVAD-fmk

- $10 \mathrm{ng} / \mathrm{mL}$ TNF and 500 nм SM

- $10 \mathrm{ng} / \mathrm{mL}$ TNF and $500 \mathrm{~nm}$ SM and $20 \mu \mathrm{m} \mathrm{zVAD-fmk}$

- $10 \mathrm{ng} / \mathrm{mL}$ TNF and $500 \mathrm{~nm}$ SM and $20 \mu \mathrm{m} \mathrm{zVAD-fmk}$ and $40 \mu \mathrm{M}$ necrostatin-1

ii. Treat wells of L929 cells for $2 \mathrm{~h}$ with the following combinations of reagents. Use three wells per condition.

- $10 \mathrm{ng} / \mathrm{mL}$ TNF + 500 nм SM + $20 \mu \mathrm{m} \mathrm{zVAD}-f m k$

- $10 \mathrm{ng} / \mathrm{mL}$ TNF $+500 \mathrm{~nm} \mathrm{SM}+20 \mu \mathrm{m} \mathrm{zVAD}$-fmk $+40 \mu \mathrm{m}$ necrostatin-1

Cells can be supplemented with other drugs or treatment combinations appropriate for the experimental goals. For treatments up to $12 \mathrm{~h}$ there is no need to change the medium.

3. Aspirate the supernatants into prelabeled FACS tubes.

This allows the collection of detached dead cells. 
4. Trypsinize cells and carefully resuspend them with their own medium (collected in Step 3). Return each cell suspension to its respective FACS tube.

5. Add $2.5 \mathrm{~mm} \mathrm{CaCl}_{2}, 5 \mu \mathrm{L} / \mathrm{mL}$ Annexin $\mathrm{V}^{\mathrm{FITC}}, 1.43 \mu \mathrm{M}$ DAPI, 20 nм TMRM, and CountBright beads $(25000 / \mathrm{mL})$, and proceed to Step 7 .

CountBright absolute counting beads are a calibrated suspension of microspheres that are brightly fluorescent across a wide range of excitation and emission wavelengths, and contain a known concentration of microspheres. For absolute counts, a specific volume of microsphere suspension is added to a specific volume of sample, so that the ratio of sample volume to microsphere volume is known. The volume of sample analyzed can be calculated from the number of microspheres counted, and can be used to correct for cell loss during analysis and to determine cell concentration.

6. Prepare controls as follows.

i. Leave one well of HT1080 $0^{\text {indRIPK3 }}$ cells and one well of L929 cells without any dye.

ii. Treat HT1080 indRIPK3 and L929 cells with each of the following single dyes. Use one well of cells per dye.

- $5 \mu \mathrm{L} / \mathrm{mL}$ Annexin $\mathrm{V}^{\mathrm{FITC}}$

- $1.43 \mu \mathrm{M}$ DAPI

- 20 nM TMRM

- CountBright beads $(25,000 / \mathrm{mL})$

7. Incubate the cells from Steps 5 and 6 for at least $20 \mathrm{~min}$ at $37^{\circ} \mathrm{C}$ in the incubator to allow the dyes to adhere.

After this, cells can be kept on ice.

8. Analyze samples using an LSRII FACS system, or equivalent.

i. Analyze the unstained control cells first and adjust the voltage and threshold.

ii. Analyze the single-stained controls, and set up a compensation matrix.

iii. Use the nonstained and single-stained control samples for gating.

The exact parameters and conditions for sorting will vary among FACS systems and facilities and should be discussed with experts in your facility.

9. Use three technical replicates per experimental condition and three biologically independent experiments for statistical analysis using Student's $t$-test.

For sample results, see Figure 1.

\section{DISCUSSION}

FACS provides a fast, objective, and quantitative method of recording of the number of dying cells in a population and is, therefore, routinely used to study cell death (Christensen et al. 2013). Annexin V is used as a probe to detect cells in which phosphatidylserine (PS) is exposed at the outer leaflet of the plasma membrane (Tait et al. 1989; Andree et al. 1990; Vermes et al. 1995). PS externalization occurs in early apoptotic cells, whereas living cells remain Annexin V negative. Although Annexin V can be used to detect apoptosis, it should be noted that necroptotic cells also become Annexin V-positive as Annexin V can bind to internal PS following cell rupture. However, when combined with PI the double-labeling procedure allows a further distinction of necrotic (Annexin V+/PI+) from early apoptotic (Annexin V+/PI-) cells (Vermes et al. 1995). Although cells that are Annexin V+/PIcan be considered to die by apoptosis at early time points, it should be noted that at late time points apoptotic cells can become Annexin V+/PI+. Therefore, it is important to combine this assay with a time-course study, and/or the use of specific inhibitors. Although the FACS method is a powerful approach to study cell death, it is not without its caveats. A particular problem is the fact that dying cells can disintegrate and the resulting cell debris cannot be captured by FACS analysis. To circumvent 
F. Wallberg et al.
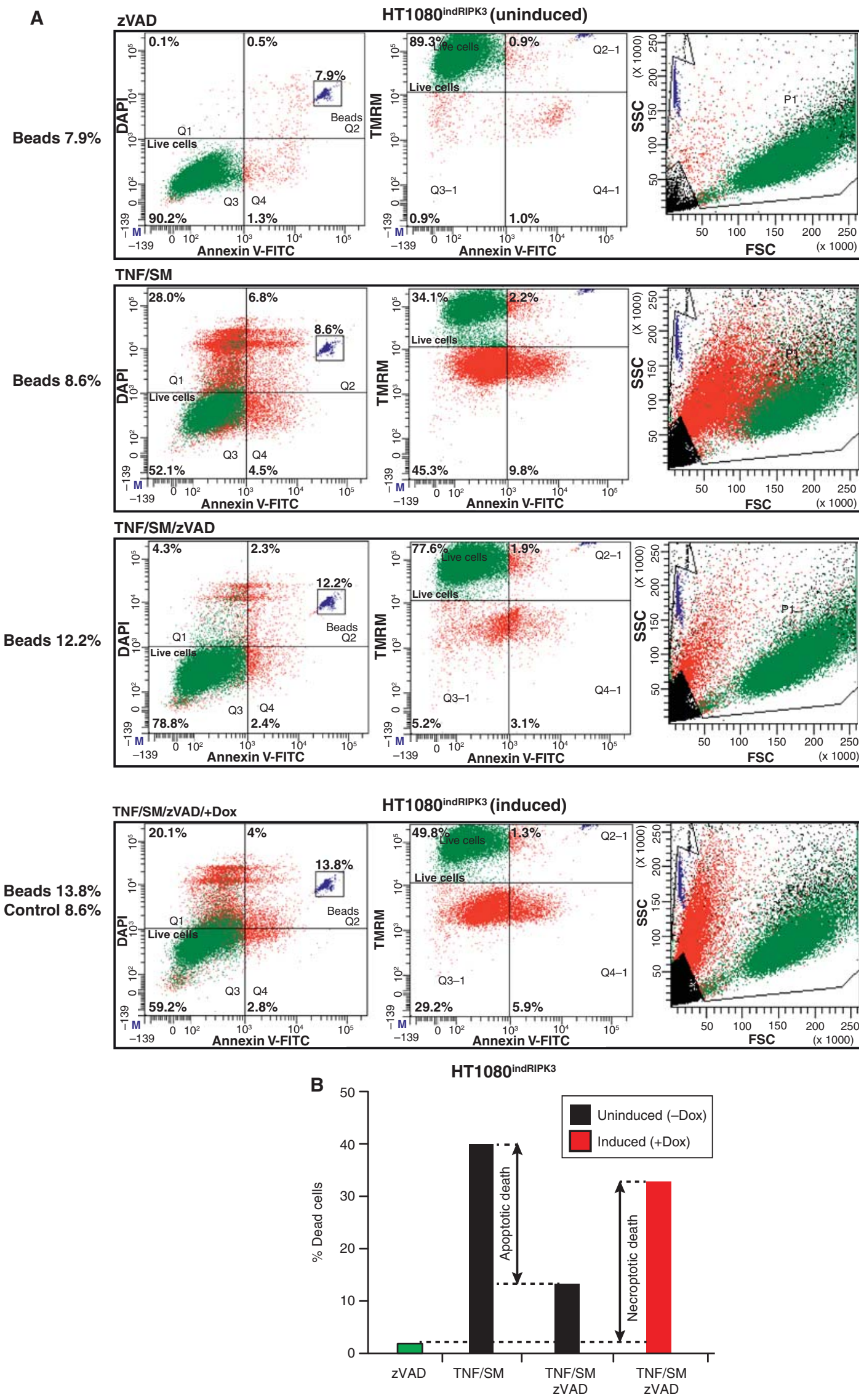

FIGURE 1. (See following page for legend.) 

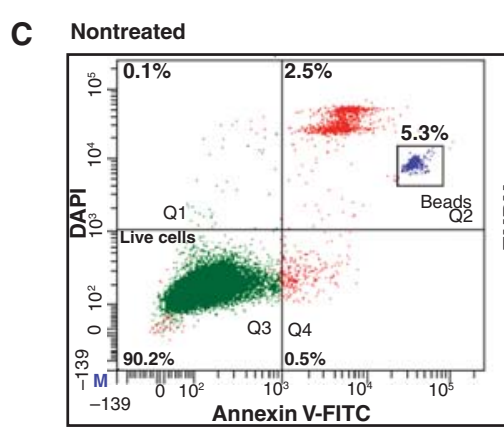

\section{L929}
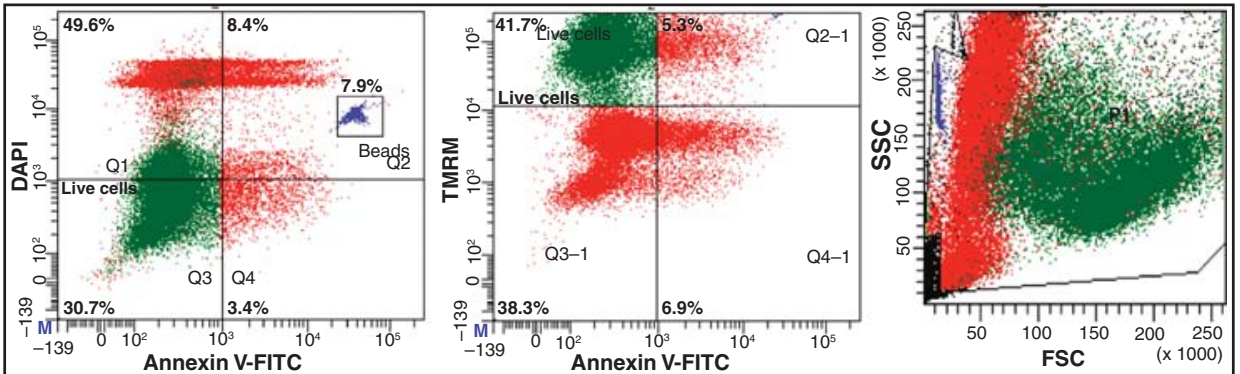

TNF/SM/ZVAD/nec-1
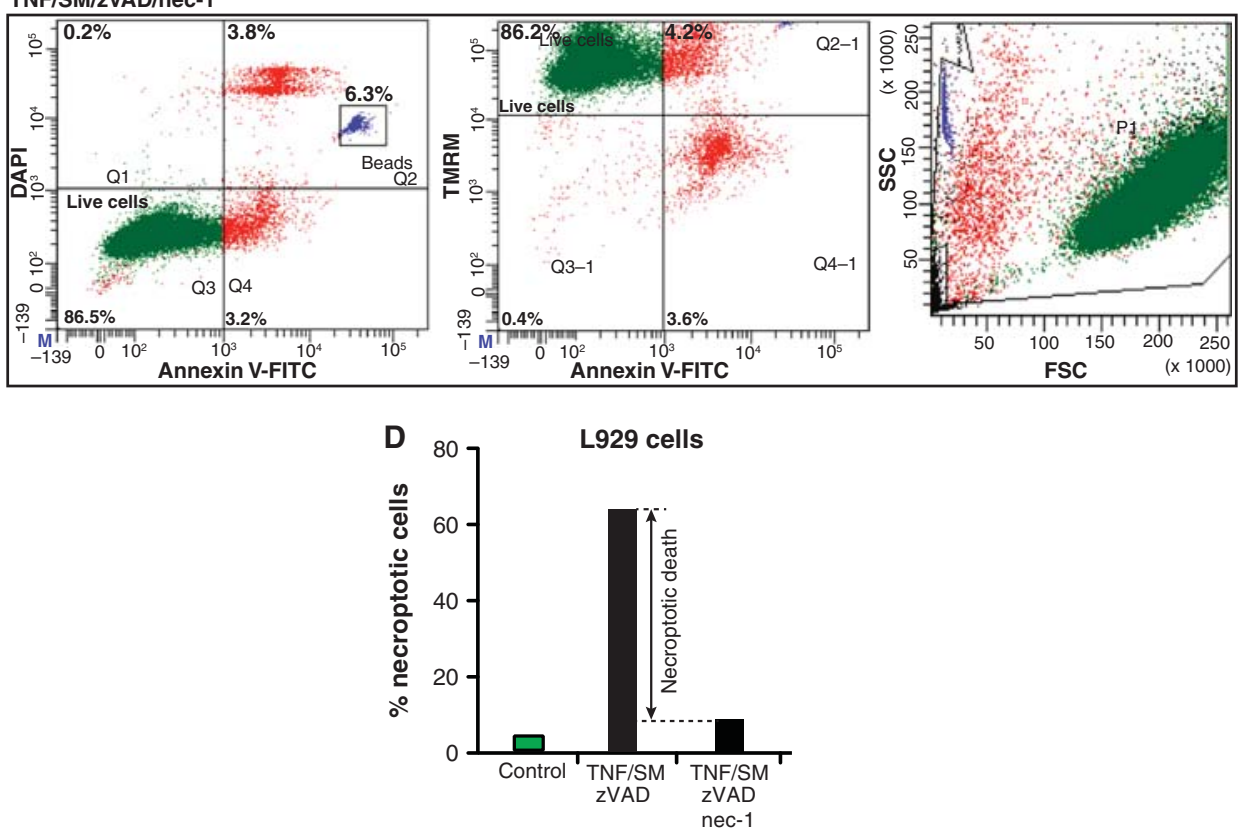

FIGURE 1. FACS analysis of cells undergoing necroptosis. $(A, B) \mathrm{HT} 1080^{\text {indRIPK3 }}$ cells were grown in the absence or presence of $100 \mathrm{ng} / \mathrm{mL}$ Dox to induce RIPK3 expression. Cells were seeded into six-well plates and cultured for $24 \mathrm{~h}$ before being treated with $20 \mu \mathrm{m}$ zVAD-fmk, $10 \mathrm{ng} / \mathrm{mL}$ TNF + 500 nм SM, or $10 \mathrm{ng} / \mathrm{mL}$ TNF + 500 nм SM + $20 \mu \mathrm{M}$ zVAD-fmk. Prior to flow cytometry, cells were trypsinized and incubated with $5 \mu \mathrm{L} / \mathrm{mL}$ Annexin $\mathrm{V}^{\mathrm{FITC}}, 1.43 \mu \mathrm{M}$ DAPI, 20 nм TMRM and CountBright ${ }^{T M}$ absolute counting beads $(25,000 / \mathrm{mL})$. (B) Graphic representation of cell death from $(A)$ expressed as \% of Annexin $\mathrm{V}^{\mathrm{FITC}}$ and DAPI-positive (dead) cells, and corrected for the loss of cells using the microsphere counting beads. $(C, D)$ L929 cells were seeded into 6-well plates for $24 \mathrm{~h}$ before being treated for

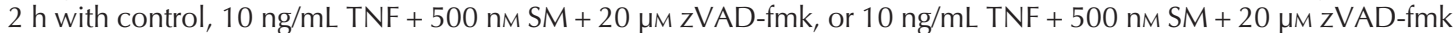
$+40 \mu \mathrm{M}$ necrostatin-1. Prior to flow cytometry, cells were trypsinized and incubated with $5 \mu \mathrm{L} / \mathrm{mL}$ Annexin $\mathrm{V}^{\mathrm{FITC}}, 1.43$ $\mu \mathrm{M}$ DAPI, 20 nм TMRM and beads (25,000/mL). (D) Graphic representation of cell death expressed as a \% of Annexin $\mathrm{V}^{\mathrm{FITC}}$ and DAPI-positive (dead) cells, and corrected for the loss of cells using the microsphere counting beads. 
F. Wallberg et al.

this problem, CountBright absolute counting beads can be used to determine how many cells were lost due to cell disintegration. When using microspheres, it is important to take into consideration that the untreated controls will continue to proliferate, which might affect the cell count. Hence, the respective treatment times should not be too long. Despite its advantages and ease of use, FACS is best complemented with time-lapse video microscopy as the combination of both methodologies more accurately captures the modality of cell death. This is especially true for some cell lines that stain poorly for Annexin V when undergoing bona fide apoptosis (Fadeel et al. 1999; Lee et al. 2013). For example, PS exposure reportedly does not occur in autophagy-deficient cells succumbing to apoptosis $(\mathrm{Qu}$ et al. 2007). Nevertheless, such cells clearly lose cell mass through membrane blebbing and nuclear shrinkage, and at later stages they undergo secondary necrosis and become PI positive.

\section{RELATED TECHNIQUES}

In addition to the method described here, there are many other FACS-based assays that can be used, such as evaluation of the percentage of sub-G0 cells after permeabilization followed by PI or 7aminoactinomycin D (7-AAD) staining (Tenev et al. 2001; Zembruski et al. 2012).

\section{ACKNOWLEDGMENTS}

We thank Katiuscia Bianchi and Hugh Paterson for technical support and insightful discussions and suggestions. We acknowledge National Health Service funding to the National Institute for Health Research Biomedical Research Centre.

\section{REFERENCES}

Andree HA, Reutelingsperger CP, Hauptmann R, Hemker HC, Hermens WT, Willems GM. 1990. Binding of vascular anticoagulant $\alpha$ (VAC $\alpha$ ) to planar phospholipid bilayers. J Biol Chem 265: 4923-4928.

Christensen ME, Jansen ES, Sanchez W, Waterhouse NJ. 2013. Flow cytometry based assays for the measurement of apoptosis-associated mitochondrial membrane depolarisation and cytochrome $c$ release. Methods 61(2): 138-145.

Fadeel B, Gleiss B, Hogstrand K, Chandra J, Wiedmer T, Sims PJ, Henter JI, Orrenius S, Samali A. 1999. Phosphatidylserine exposure during apoptosis is a cell-type-specific event and does not correlate with plasma membrane phospholipid scramblase expression. Biochem Biophys Res Commun 266: 504-511.

Kapuscinski J. 1995. DAPI: A DNA-specific fluorescent probe. Biotech Histochem 70: 220-233.

Lee SH, Meng XW, Flatten KS, Loegering DA, Kaufmann SH. 2013. Phosphatidylserine exposure during apoptosis reflects bidirectional traffick- ing between plasma membrane and cytoplasm. Cell Death Differ 20: 64-76.

Qu X, Zou Z, Sun Q, Luby-Phelps K, Cheng P, Hogan RN, Gilpin C, Levine B. 2007. Autophagy gene-dependent clearance of apoptotic cells during embryonic development. Cell 128: 931-946.

Tait JF, Gibson D, Fujikawa K. 1989. Phospholipid binding properties of human placental anticoagulant protein-I, a member of the lipocortin family. J Biol Chem 264: 7944-7949.

Tenev T, Marani M, McNeish I, Lemoine NR. 2001. Pro-caspase-3 overexpression sensitises ovarian cancer cells to proteasome inhibitors. Cell Death Differ 8: 256-264.

Vermes I, Haanen C, Steffens-Nakken H, Reutelingsperger C. 1995. A novel assay for apoptosis. Flow cytometric detection of phosphatidylserine expression on early apoptotic cells using fluorescein labelled Annexin V. I Immunol Methods 184: 39-51.

Zembruski NC, Stache V, Haefeli WE, Weiss J. 2012. 7-Aminoactinomycin D for apoptosis staining in flow cytometry. Anal Biochem 429: 79-81. 


\section{Analysis of Apoptosis and Necroptosis by Fluorescence-Activated Cell Sorting}

Fredrik Wallberg, Tencho Tenev and Pascal Meier

Cold Spring Harb Protoc; doi: 10.1101/pdb.prot087387

\begin{tabular}{|c|c|}
\hline $\begin{array}{r}\text { Email Alerting } \\
\text { Service }\end{array}$ & Receive free email alerts when new articles cite this article - click here. \\
\hline $\begin{array}{l}\text { Subject } \\
\text { Categories }\end{array}$ & $\begin{array}{l}\text { Browse articles on similar topics from Cold Spring Harbor Protocols. } \\
\text { Apoptosis Assays ( } 73 \text { articles) } \\
\text { Cell Biology, general (1382 articles) } \\
\text { Fluorescence ( } 517 \text { articles) } \\
\text { Fluorescence, general (341 articles) }\end{array}$ \\
\hline
\end{tabular}

